\title{
EVALUATION OF PROTEIN AND IRON ABSORPTION OF MOCAF-BASED WEANING FOOD
}

\author{
[Evaluasi Penyerapan Protein dan Zat Besi Makanan Pendamping \\ ASI Berbasis Mocaf]
}

\section{Lia Ratnawati ${ }^{\star}$, Dewi Desnilasari, Novita Indrianti, Enny Sholichah, and Dita Kristanti}

Research Center for Appropriate Technology, Indonesian Institute of Sciences (LIPI), Subang

Received May $12^{\text {nd }} 2020 /$ Accepted January $15^{\text {th }} 2021$

\begin{abstract}
Weaning food biscuit based on mocaf (modified cassava flour) with substitution of soybean, mung bean and red kidney bean flour is expected increasing protein of the product. However, in the legumes flour there are anti-nutritional agent that can affect the absorption of other nutrient such as protein and iron. The purpose of this study was to evaluate the absorption of protein and iron from mocaf basedweaning food. Protein and iron absorption were determined from weaning food (biscuit) using SpragueDawley rats, 3 weeks old, weight $70-80 \mathrm{~g}$ for $0,30,60,90$, and 120 minutes. The treatments of this study were mocaf biscuits (as a control), biscuits with substitution of soybean flour (MSF), mung bean flour (MMF), red kidney bean flour (MRF) and commercial biscuits (CB). The highest protein absorption of control, MSF and MRF were at 120 minutes with absorption percentages 27.76, 38.94, and 9.35\%, respectively. Samples MMF and CB had the highest protein absorption at 60 and 90 minutes, with absorption percentages 15.58 and $37.57 \%$. Meanwhile, the highest iron absorption of control, MSF and MMF were at 90 minutes with absorption percentages $53.86,4.71$, and $54.29 \%$. Samples MRF and CB had highest iron absorption at 60 minutes with absorption percentages 7.97 and $69.76 \%$, respectively. The MSF sample had highest protein absorption than other samples. Meanwhile, the MMF sample had an iron absorption value that approached to commercial biscuit.
\end{abstract}

Keywords: absorption, iron, mocaf, protein, weaning food

\begin{abstract}
ABSTRAK
Makanan Pendamping Air Susu Ibu (MP-ASI) berupa biskuit berbasis mocaf dengan substitusi tepung kedelai, kacang hijau dan kacang merah diharapkan dapat meningkatkan kandungan proteinnya. Akan tetapi, pada tepung kacang-kacangan tersebut mengandung zat antigizi yang dapat mempengaruhi penyerapan zat gizi seperti protein dan zat besi. Studi ini bertujuan untuk mengevaluasi penyerapan protein dan zat besi dari biskuit MP-ASI berbasis mocaf. Analisis penyerapan protein dan zat besi dilakukan secara in situ dengan menggunakan tikus jenis Sprague-Dawley berumur 3 minggu, berat 70-80 g, selama 0, 30, 60, 90, dan 120 menit. Perlakuan dalam studi ini meliputi biskuit mocaf (kontrol), biskuit dengan substitusi tepung kedelai (MSF), tepung kacang hijau (MMF), tepung kacang merah (MRF) dan biskuit komersial (CB). Penyerapan protein tertinggi sampel kontrol, MSF dan MRF terjadi pada menit ke120 dengan persentase penyerapan berturut-turut 27,76; 38,94; dan 9,35\%. Sampel MMF dan CB menunjukkan penyerapan protein tertinggi pada menit ke-60 dan 90 dengan persentase penyerapan protein sebesar 15,58 dan 37,57\%. Penyerapan zat besi tertinggi sampel kontrol, MSF dan MMF terjadi pada menit ke-90 dengan persentase penyerapan 53,86; 4,71; dan 54,29\%. Sampel MRF dan CB memiliki penyerapan zat besi tertinggi pada menit ke-60 dengan persentase penyerapan berturut-turut sebesar 7,97 dan 69,76\%. Sampel MSF memiliki nilai penyerapan protein tertinggi diantara sampel lainnya. Sementara itu, sampel MMF memiliki nilai penyerapan zat besi yang mendekati nilai penyerapan biskuit komersial.
\end{abstract}

Kata kunci: mocaf, MP-ASI, penyerapan, protein, zat besi

\footnotetext{
The manuscript has been presented in The $16^{\text {th }}$ Asean Food Conference 2019, October $15^{\text {th }}-18^{\text {th }} 2019$, Bali-Indonesia
} *Corresponding Author: E-mail: lia.romeo@gmail.com 


\section{INTRODUCTION}

The prevalence of undernutrition and micronutrient deficiencies is common in infants and young children in developing countries with an age range of 6-23 months. It can increase the risk of underweight, stunting and death (Fekadu et al., 2015). Total diet study (SDT) in 2014 found that the average level of macro and micro nutrient adequacy in infants was still lacking in several regions of Indonesia (Kemenkes, 2016). Micronutrient deficiencies such as vitamin A, zinc, iron and iodine are still common, even though it is very important to prevent stunting (Ahmed et al., 2012). The government programmed the provision of weaning food in the form of instant powder and biscuits. Weaning food is nutritious food other than breast milk that is given to infants aged 6 months or older or based on medical indications until the child is 24 months of age to achieve adequate nutrition.

According to Indonesian National Standard, main ingredients for making weaning food biscuits are cereals (rice, sorghum, corn, wheat, barley, oats, rye, millet, buckwheat), tubers (cassava, sweet potato, arrowroot, potato, gembili), starch (sago, sugar palm starch), legumes (mung bean, red bean, cowpea, beans), grain containing oil (soybean, peanut, sesame), milk, fish, meat, poultry, fruit or others appropriate ingredients (BSN, 2005). Biscuits as weaning food in the common market mostly made from wheat flour. However, Indonesia rich of local materials as sources of weaning food ingredients such as modified of cassava flour (mocaf). Mocaf is made from fermented cassava by lactic acid bacteria. Fermentation changes the characteristic of cassava flour, it contents higher carbohydrate and improves the physical properties. According Meitha et al. (2016), fermentation affects the properties of cassava flour. It reduced the HCN content, swelling power and solubility. Mocaf was shown to have brighter color, neutral aroma, softer and lower cyanogenic content (Kresnowati et al., 2019). On the other hand, mocaf also has a low protein i.e. 1.77\% (Afifah and Ratnawati, 2017).

Mocaf based-weaning food (biscuit) is a weaning food made from mocaf with a substitution of legumes flour (soybean, mung bean and red kidney bean). Substitution aims to increase protein and iron content from weaning food. It is known that legumes seed has a high protein content which is between $20-40 \%$ in the dry matter (Esbersdobler et al., 2017). The minimum protein content of weaning food biscuit is $6 \mathrm{~g} / 100 \mathrm{~g}$ (BSN, 2005). However, the addition of legume flour is also feared to reduce the absorption of protein and iron because of the antinutritional compounds. Several antinutritional compounds in legumes seed such as tannins, phytic acid, trypsin inhibitors, protease inhibitor, lectin, alkaloid, polyphenol and oligosaccharides cause flatulence (Muzquiz et al., 2012). Minerals, proteins, enzymes, and starches was reported can be complexed by phytic acid (Silva and Bracarense, 2016), alkaloid and polyphenol could decrease the protein bio-availability (Muzquiz et al., 2012). This study aims to evaluate the protein and iron absorption of mocaf-based weaning food with substitution legumes flour.

\section{MATERIALS AND METHODS}

\section{Materials}

Modified cassava flour (mocaf) was purchased from Small Medium Enterprises (Harapan Jaya) at Subang, Indonesia. Soybean (Glycine max) and mung bean (Vigna radiata) were purchased from Subang local market, red kidney bean (Phaseolus vulgaris) was purchased from local market at Lembang. Other ingredients were used in this study include eggs (yolk), sugar (Gulaku), banana (Musa acuminata), unsalted butter (Anchor), baking powder (Koepoe Koepoe) and lecithin were prepared.

\section{Preparation of legume flour}

The soybean, mung bean and red kidney bean were sorted to remove extraneous materials and damaged seeds. The seeds were washed and soaked using water at $60-70^{\circ} \mathrm{C}$ for 3 hours. After that, the seeds were dehulled and dried using cabinet dryer (Jenn-Chiang Machinery Works Co., LTD, Taiwan) at $50^{\circ} \mathrm{C}$ for 12 hours. The dried seeds were reduced particle size using disk mill and sieved using a 40 mesh screen to obtain the flour (Ratnawati et al., 2019).

\section{Preparation of biscuit}

Biscuits were prepared according to the method reported in the previous study (Ratnawati et al., 2020). The formulation of biscuits could be seen in Table 1. The biscuits were prepared briefly; egg yolk, sugar, unsalted butter and lecithin were mixed using mixer (high-speed) (Philips HR 1538, Netherland) until the mixture became fluffy. Banana was mashed until it becomes puree using chopper (Philips HR 2939, Netherland). Then, banana puree and baking powder were added and stirred until homogeneous using mixer (low-speed). After that, the mocaf and legumes flour were added and mixed manually by hand until become smooth dough. The dough was sheeted (thickness $7 \mathrm{~mm}$ ) using dough sheeter (Getra) and baked using oven (Mah Yi, China) at $150^{\circ} \mathrm{C}$ for 10 minutes. Subsequently, the biscuits were inverted and baked again at $100^{\circ} \mathrm{C}$ for 20-30 minutes. Last, the biscuits were cooled to room temperature and stored in polypropylene (PP) plastic bags for further analysis. 
Table 1. Formulation of weaning food biscuit

\begin{tabular}{lcccc}
\hline \multirow{2}{*}{ Ingredients (\%) } & \multicolumn{4}{c}{ Samples } \\
\cline { 2 - 5 } & Control & MSF & MMF & MRF \\
\hline Mocaf & 50 & 30 & 30 & 30 \\
Soybean flour & - & 20 & - & - \\
Mung bean flour & - & - & 20 & - \\
Red kidney & - & - & - & 20 \\
bean flour & & & & \\
Egg yolk & 10 & 10 & 10 & 10 \\
Sugar & 14 & 14 & 14 & 14 \\
Banana puree & 14 & 14 & 14 & 14 \\
Unsalted butter & 10 & 10 & 10 & 10 \\
Lecithin & 1 & 1 & 1 & 1 \\
Baking powder & 1 & 1 & 1 & 1 \\
\hline
\end{tabular}

\section{Experimental design}

The experimental design in this study using a completely randomized design with one factor namely type of legume flour. The codes of biscuit sample were namely control (mocaf biscuits without addition legume flour), MSF (mocaf-soybean flour), MMF (mocaf-mung bean flour), MRF (mocaf-red kidney bean flour), and CB (commercial biscuit).

\section{Chemical analysis of biscuit}

Protein content of biscuit was analyzed by combustion method using a protein analyzer (DuMaster D-480, Buchi, Switzerland). Iron content was measured using Atomic Absorption Spectrometer (ContrAA 300 Analytic Jena, Germany) as described earlier by Luo et al. (2013). The procedure for iron analysis was as follows: $10 \mathrm{~g}$ samples were added 5 $\mathrm{mL} \mathrm{HNO}_{3}$ (Merck, Germany) and $1 \mathrm{~mL} \mathrm{HClO}_{4}$ (Merck, Germany). After that, the solution was digested in the heating plate until the volume was reduced. After digestion, the solution was added 10 $\mathrm{mL}$ distilled water and filtered in a $25 \mathrm{~mL}$ volumetric flask using filter paper. Then, the distilled water was added to the mark and read the solution with AAS at $248.3 \mathrm{~nm}$.

Phytic acid was determined by spectrophotometry method (Davies and Reid, 1979). Procedure for phytic acid analysis was as follows: $10 \mathrm{~g}$ samples were extracted with $50 \mathrm{~mL} \mathrm{HNO}_{3} 0.5 \mathrm{M}$ for 2 hours with continuous shaking. After filtering, phytic acid analysis was performed on filtrate. Sodium phytate was used for preparation of a standard phytic acid solution. In the test tube, $0.5 \mathrm{~mL}$ filtrate or $\mathrm{Na}$ phytate solution $(0.2 \mathrm{mM})$ was added with $0.9 \mathrm{~mL}$ $\mathrm{HNO}_{3} 0.9 \mathrm{M}$ and $1 \mathrm{~mL} \mathrm{FeCl} 30.3 \mathrm{mM}$. After mixing, the test tubes were stoppered and placed in a boiling water bath for 20 minutes. When cooled to room temperature, $5 \mathrm{~mL}$ amyl alcohol was added followed by $1 \mathrm{~mL}$ of a solution of ammonium thiocyanate $0.1 \mathrm{mM}$. After that, the solution was centrifuged at $1500 \mathrm{rpm}$ for 10 minutes. After centrifuging, the intensity of the color in the amyl layer was determined at $465 \mathrm{~nm}$ using spectrophotometer against an amyl alcohol 'blank', exactly
15 min after addition of ammonium thiocyanate. Since the principle of the method is based on the observation that ferric ions complexed with phytate at $\mathrm{pH}$ 1.0-2.0 cannot react with thiocyanate ion to give the characteristic pink complex, the extinction at $465 \mathrm{~nm}$ in the amyl layer is inversely related to the phytate anion concentration. The amount of phytic acid content was expressed as $\mathrm{mg} / \mathrm{g}$ dry sample.

Protein digestibility of biscuit was evaluated by in vitro using Tanaka method (Tanaka et al., 1978). Briefly, $200 \mathrm{mg}$ sample was dissolved in $9 \mathrm{~mL}$ Walpole buffer $(\mathrm{pH} 2.0 ; 0.2 \mathrm{~N})$ and $1 \mathrm{~mL}$ pepsin $(2 \%)$ (Merck, Germany) with constant stirring for 1.5 hours at shaker water bath. After that, the separation of supernatant from mixture was carried out through centrifugation at $3000 \mathrm{rpm}$ for 20 minutes. The supernatant $(5 \mathrm{~mL})$ was put into a test tube and Trichloroacetic acid solution (5 mL, $20 \%$ ) was added. Then, the mixture was incubated (1.5 hours) and filtered (Whatman, No. 41). Nitrogen in the filtrate was analyzed using the micro Kjeldahl method. Crude protein of sample was also determined using micro Kjeldahl as nitrogen total sample. Protein digestibility was calculated using following equation:

$\%$ In Vitro Protein Digestibility $=\frac{\mathrm{A}-\mathrm{B}}{\mathrm{A}}$

$A=\%$ protein in sample before digestion, $B=\%$ protein in sample after pepsin digestion.

\section{In situ analysis}

Protein and iron absorption were determined by in situ method using Sprague-Dawley rats, 3 weeks old, weight 70-80 g, each group consists of 3 rats. The rats were acclimated for 5 days and fed with AIN 93G before study. In situ method according to Schleiffer et al. (1993) with some modification. The rats were anesthetized using ketamine at a dose of $60 \mathrm{mg} / \mathrm{kg}$ body weight intra muscularly and then surgically performed. The duodenum and proximal portions of the jejunum as long as $25 \mathrm{~cm}$ were cannulated intraluminal. One tube (Versilic $3 / 1 \mathrm{~mm}$ ) was entered into the duodenum through the prestomach and pylorus, while the other tube (Versilic $5 / 1 \mathrm{~mm}$ ) was entered into the end distal at the last segment. Then rinse using $0.9 \% \mathrm{NaCl}$ solution at $37^{\circ} \mathrm{C}$. Rats were placed in a box and conditioned at $37^{\circ} \mathrm{C}$. The next step was infusing intraluminal the intestinal segment with $0.9 \% \mathrm{NaCl}$ solution containing a sample solution using an infusion pump. The sample solution was prepared by dissolving $0.47 \mathrm{~g}$ of biscuits using distilled water up to $150 \mathrm{~mL}$. The biscuit sample weight was calculated by multiplying the biscuit serving size $(26 \mathrm{~g})$ with the conversion factor of human to rats $(0.018)$. The sample solution was the liquid that passed through 
the rat intestine than it was collected every period of 30 minutes for 2 hours. The sample solutions of about $30 \mathrm{~mL}$ were collected in a vial and stored in the refrigerator for further analysis. The solutions were analyzed protein and iron content. In situ analysis had received an ethical clearance certificate No. 009/EC-FKH/Eks./2019.

\section{Statistical analysis}

An analysis of variance (ANOVA) and Duncan test (confidence level, $\alpha=0.05$ ) were performed on the obtained results in order to establish significant differences. SPSS version 13 was used for data treatment and statistical analysis. The data are shown as mean \pm SEM.

\section{RESULTS AND DISCUSSION}

\section{Chemical properties of biscuit}

The weaning food biscuit with substitution of legumes flour (soybean, mung bean and red kidney bean flour) were evaluated the chemical properties that were protein, iron, phytic acid and protein digestibility and compared with control (mocaf biscuit) and commercial biscuit as shown in Table 2.

Weaning food biscuit with soybean flour substitution (MSF) had the highest protein content. It is due to the soybean flour had the highest protein content i.e. $40.94 \%$, while the mung bean and red kidney bean flour have the protein content $24.99 \%$ and $22.53 \%$, respectively (Ratnawati et al., 2019). Meanwhile, weaning food biscuit with mung bean flour substitution (MMF) had the highest iron content. The phytic acid content of weaning food biscuits were not significantly different. The highest protein digestibility was MRF samples.

\section{Protein absorption of biscuit}

The results of the protein content absorption of weaning food biscuit were presented in Figure 1. The protein absorption of control, MMF, and CB were started at 60 minutes, while the protein absorption of MSF and MRF biscuit were started at 90 and 120 minutes, respectively. The highest protein absorption of control, MSF, and MRF biscuit were at 120 minutes with absorption percentages 27.76,
38.94, and $9.35 \%$, respectively. The MMF biscuit and $\mathrm{CB}$ had the highest protein absorption at 60 and 90 minutes, with absorption percentages 15.58 and $37.57 \%$. The protein absorption times of MSF and MRF biscuit were slower than those in control, MMF and CB. The MSF biscuit had the highest protein absorption percentages than the other samples. It might be caused the protein digestibility of soybean flour was higher $(80.54 \%)$ than mung bean (33.36\%) and red kidney bean flour (39.59\%) (Ratnawati et al., 2019). Another study reported that the protein digestibility of soybean, mung bean and red kidney bean are 85.40, 52.03, and 68.22\% (Ogodo et al., 2018; Viswanathan and Ho, 2014; Oghbael and Prakash, 2016).

\section{Iron absorption of biscuit}

The results of the iron content absorption of weaning food biscuit were presented in Figure 2. The results showed that iron absorption of weaning food biscuits were started at 60 minutes of experiment. The optimal iron absorption of control, MSF and MMF biscuits were occurred at 90 minutes with absorption percentage of 53.86, 4.71, and $54.29 \%$, while MRF and CB were occurred at 60 minutes with absorption percentage of 7.97 and $69.76 \%$, respectively. The MMF biscuit had a highest iron absorption compared to control, MSF and MRF biscuits. The iron absorption of MRF biscuit was higher than MSF biscuit. However, the iron absorption of legume biscuits was lower than CB.

The iron content of MSF $(3.89 \pm 0.00 \mathrm{mg} / 100 \mathrm{~g})$, MMF $(15.32 \pm 0.08 \mathrm{mg} / 100 \mathrm{~g})$, and MRF $(4.15 \pm 0.02$ $\mathrm{mg} / 100 \mathrm{~g})$ biscuits were higher than control (1.93 $0.09 \mathrm{mg} / 100 \mathrm{~g})$ and CB $(3.33 \pm 0.07 \mathrm{mg} / 100 \mathrm{~g})$. However, the iron absorption of control and $C B$ were higher than MSF, MMF, and MRF biscuits. The type of iron contained in a food affect the iron absorption rate. The type of iron in a legume such as red kidney bean, mung bean and soybean is a non-heme iron. The absorption of non-heme iron was less than $5 \%$, it was influenced by a balance between inhibiting (phytic acid, tannin, phosphate) and enhancers (amino acid, ascorbic acid) factors (Tsalissavrina et al., 2012).

Table 2. Chemical properties of weaning food biscuit

\begin{tabular}{lccccc}
\hline \multirow{2}{*}{ Parameter } & \multicolumn{5}{c}{ Sample } \\
\cline { 2 - 6 } & Control & MSF & MMF & MRF & CB \\
\hline Protein $(\%)$ & $4.08 \pm 0.01^{\mathrm{a}}$ & $11.82 \pm 0.04^{\mathrm{e}}$ & $10.05 \pm 0.02^{\mathrm{d}}$ & $9.64 \pm 0.03^{\mathrm{c}}$ & $8.56 \pm 0.01^{\mathrm{b}}$ \\
Iron $(\mathrm{mg} / 100 \mathrm{~g})$ & $1.98 \pm 0.03^{\mathrm{a}}$ & $3.89 \pm 0.00^{\mathrm{c}}$ & $15.32 \pm 0.06^{\mathrm{e}}$ & $4.16 \pm 0.02^{\mathrm{d}}$ & $3.33 \pm 0.05^{\mathrm{b}}$ \\
Phytic acid $(\mathrm{mg} / \mathrm{g})$ & NA & $4.28 \pm 0.12^{\mathrm{a}}$ & $4.35 \pm 0.10^{\mathrm{a}}$ & $4.29 \pm 0.21^{\mathrm{a}}$ & $\mathrm{NA}^{\mathrm{a}}$ \\
Protein digestibility $(\%)$ & NA & $66.92 \pm 0.05^{\mathrm{a}}$ & $88.69 \pm 0.17^{\mathrm{b}}$ & $90.77 \pm 0.28^{\mathrm{c}}$ & NA \\
\hline
\end{tabular}

Note: Control= Biscuit made from mocaf; MS= biscuit made from mocaf-soybean flour; MMF= Biscuit made from mocaf-

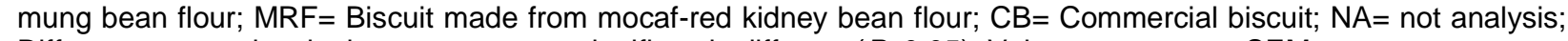
Different superscripts in the same row are significantly different $(P<0.05)$; Values are mean \pm SEM 


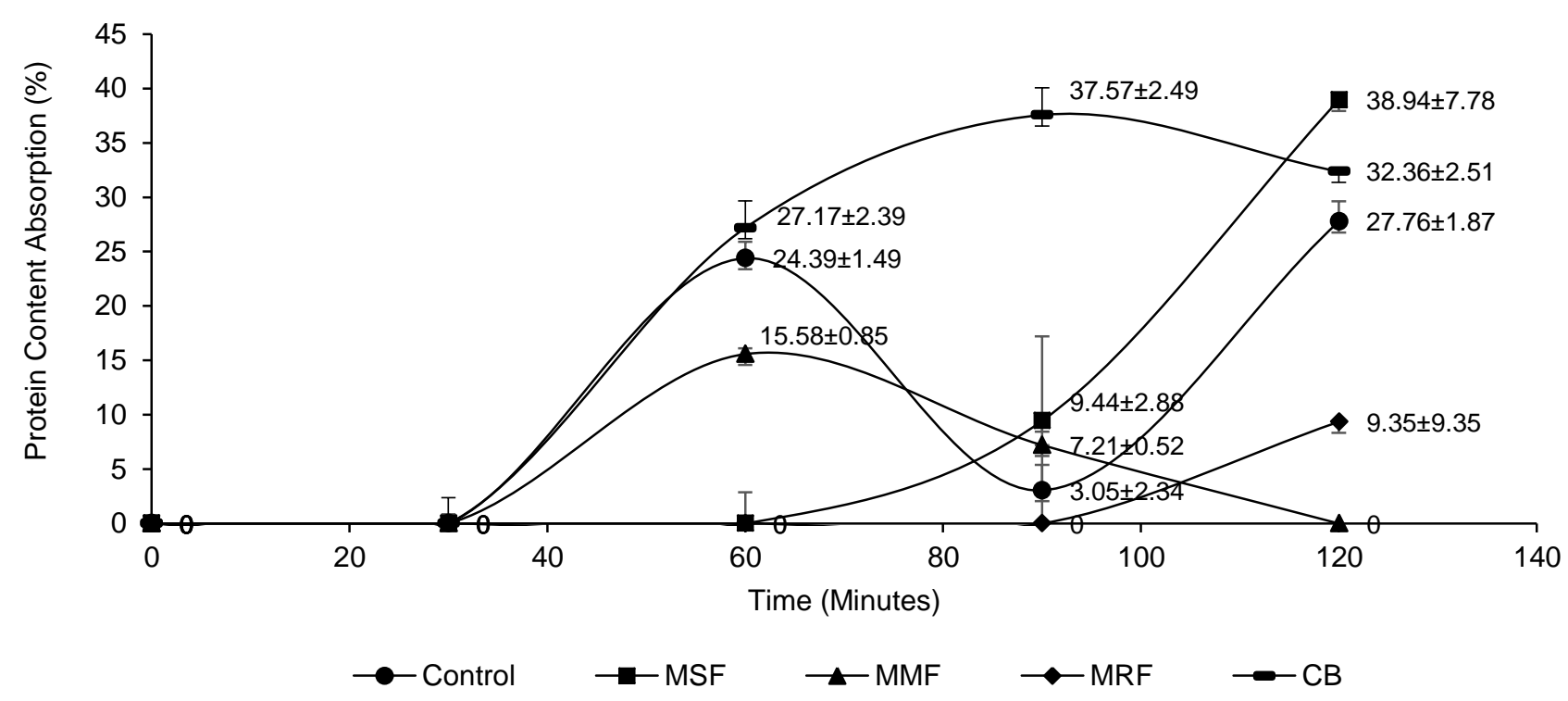

Note: Control= biscuit made from mocaf; $M S F=$ biscuit made from mocaf-soybean flour; MMF= biscuit made from mocafmung bean flour; MRF= biscuit made from mocaf-red kidney bean flour; $\mathrm{CB}=$ commercial biscuit. Values are mean \pm SEM

Figure 1. Protein content absorption (\%) of samples during 120 minutes

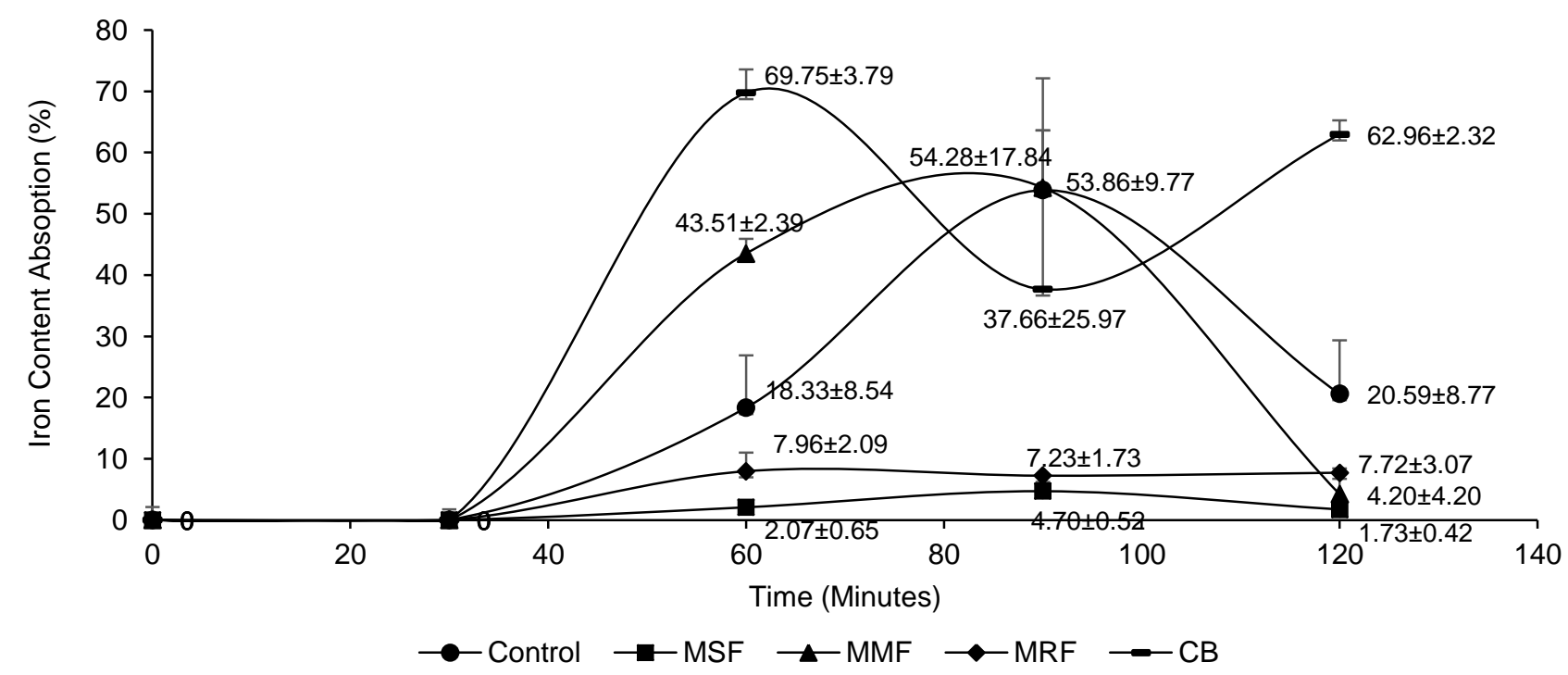

Note: Control= biscuit made from mocaf; MSF= biscuit made from mocaf-soybean flour; MMF= biscuit made from mocafmung bean flour; $\mathrm{MRF}=$ biscuit made from mocaf-red kidney bean flour; $\mathrm{CB}=$ commercial biscuit. Values are mean \pm SEM

Figure 2. Iron content absorption (\%) of samples during 120 minutes

Legume such as red kidney bean, mung bean and soybean contain of phytic acid, it is an antinutrient compound. The phytic acid content of MSF, MMF and MRF biscuit were 4.28 $\pm 0.16,4.35 \pm 0.13$, and $4.29 \pm 0.29 \mathrm{mg} / \mathrm{g}$, respectively, it was not significantly different. These results were not in accordance with previous studies, the phytic acid content of soybean flour $(2.92 \%)$ was higher than mung bean flour (1.79\%) and red kidney bean flour (1.58\%) (Ratnawati et al., 2019). In another studies, reported that the phytic acid content of soybean, mung bean and red kidney bean were about 22.50$35.01,4.84-5.20$, and $1.38-5.44 \mathrm{mg} / \mathrm{g}$, respectively 
(Kumari et al., 2014; Nakitto et al., 2014; Luo et al., 2013; Mohamed et al., 2011).

The phytic acid content of legume caused the iron absorption of MSF, MMF and MRF biscuit lower than control and $\mathrm{CB}$. In control biscuits without the addition of legume flour, the possibility of containing phytic acid from the raw material, namely mocaf and banana that lower than legume flour. The phytic acid content of fermented cassava flour and ripe banana were 129.2 and $0.24 \mathrm{mg} / 100 \mathrm{~g}$ (Oboh and Elusiyan, 2007; Garcia et al., 2015). The highest iron absorption was MMF biscuit, while the lowest was MSF biscuit. The difference of iron absorption was caused by the phytic acid content of this legumes. The iron absorption of whole grain cereals and legume porridge that containing of phytic acid $(\sim 1$ $\mathrm{g} / 100 \mathrm{~g}$ ) may be as low $2-3 \%$ even in subject who deficiency iron (Hurrel, 2003). The phytic acid had associated with reduced mineral absorption by insoluble phytate-mineral complexes. The phytic acid structure had a phosphate groups with high density of negatively charged which could bind a mineral such as iron and form non-availability complexes for intestinal absorption (Tadele, 2015). The phytic acid chelates the micronutrient such as iron caused it unavailable for digestion because they lack enzyme phytase in digestive track (Gupta et al., 2015).

The other iron absorption inhibitor is tannin. Legumes such as red kidney bean, soybean, and mung bean also contain tannin which inhibit iron absorption. The tannin content in the raw of red kidney bean, soybean, and mung bean were 0.03$1.26 \mathrm{mg} / \mathrm{g}$ (Parmar et al., 2017), $15.9 \mathrm{mg} / \mathrm{g}$ (Sharma et al., 2013), and $4.53 \mathrm{mg} / \mathrm{g}$ (Hussain et al., 2011), respectively. The in vitro study of Glahn et al. (2002) showed that tannic acid was a potent inhibitor of nonheme iron uptake.

Reducing phytic acid and tannin had been shown to improve the nutritional value and mineral bioavailability of legumes. The research was conducted by Koréissi-Dembélé et al. (2013), shown that iron absorption of fonio porridge in West African women increased (from 2.6 to $8.3 \%$ ) due to dephytinisation with intrinsic wheat phytase and iron fortification. The other method that has been developed to reduce phytic acid in legume is germination. Tajoddin et al. (2011) reported that soaking the mung beans for 12 hours than followed by germination for 48 hours reduced $60-73 \%$ of phytic acid content. Germination of soybeans and mung beans for 4 days reduced 57.5 and $76.0 \%$ of phytic acid, respectively, and increased the bioavailability of zinc and iron (Wang et al., 2015). Other studies have also shown that soaking, dehulling, cooking, roasting, germination and fermenting reduce tannin and phytic acid content of soybean, mung bean and kidney bean (Mohamed et al., 2011; Agume et al., 2017). The decline in inhibitor factor content in legumes may increase the absorption of iron content.

\section{CONCLUSION}

The highest protein and iron absorption were the biscuit with substitution of soybean flour (MSF) and mung bean flour (MMF) with the absorption values 38.94 and $54.29 \%$, respectively. The MSF sample had highest protein absorption than other samples. Meanwhile, the MMF sample had an iron absorption value that approached to commercial biscuit.

\section{ACKNOWLEDGEMENT}

The author gratefully acknowledges to Research Center for Appropriate Technology, Indonesian Institute of Sciences, Indonesia and the financial support by Ministry of Research, Technology, and Higher Education, Indonesia through INSINAS.

\section{REFERENCES}

Afifah N, Ratnawati L. 2017. Quality assessment of dry noodles made from blend of mocaf flour, rice flour and corn flour. IOP Conf. Series: Earth and Environ Sci 101: 012021. DOI: 10.1088/ 1755-1315/101/1/012021.

Agume ASN, Njintang NY, Mbofung CMF. 2017. Effect of soaking and roasting on the physicochemical and pasting properties of soybean flour. Foods 6: 1-11. DOI: 10.3390/foods60200 12.

Ahmed T, Hossain M, Sanin KI. 2012. Global burden of maternal and child undernutrition and micronutrient deficiencies. Ann Nutr Metab 6: 8-17. DOI: 10.1159/000345165.

[BSN] Badan Standardisasi Nasional. 2005. Makanan Pendamping Air Susu Ibu (MP-ASI)Bagian 2: Biskuit. Badan Standardisasi Nasional, Jakarta.

Davies BNT, Reid H. 1979. An evaluation of the phytate, zinc, copper, iron and manganese contents of, and $\mathrm{Zn}$ availability from, soyabased textured-vegetable-protein meat- substitutes or meat-extenders. Brit J Nutr 41: 579589. DOI: 10.1079/BJN19790073. 
Esbersdobler HF, Barth CA, Jahreis G. 2017. Legumes in human nutrition: Nutrient content and protein quality of pulses. Ernährungs Umschau 64: 134-139. DOI: 10.4455/eu.2017.034.

Fekadu Y, Mesfin A, Haile D, Stoecker BJ. 2015. Factors associated with nutritional status of infants and young children in Somali Region, Ethiopia: A cross-sectional study. BMC Public Health 15: 1-9. DOI: 10.1186/s12889-015-21907.

Garcia OP, Martinez M, Romano D, Camacho M, de Moura FF, Abrams SA, Khanna HK, Dale JL, Rosado JL. 2015. Iron absorption in raw and cooked bananas: A field study using stable isotopes in women. Food Nutr Res 59: 1-7. DOI: 10.3402/fnr.v59.25976.

Glahn RP, Wortley GM, South PK, Miller DD. 2002. Inhibition of iron uptake by phytic acid, tannic acid, and $\mathrm{ZnCl}_{2}$ : Studies using an in vitro digestion/Caco-2 Cell Model. J Agric Food Chem 50: 390-395. DOI: 10.1021/jf011046u.

Gupta RK, Gangoliya SS, Singh NK. 2015. Reduction of phytic acid and enhancement of bioavailable micronutrients in food grains. J Food Sci Technol 52: 676-684. DOI: 10.1007/s13197013-0978-y.

Hurrel R. 2003. Influence of vegetable protein sources on trace element and mineral bioavailability. J Nutr 133: 2973S-2977S. DOI: 10. 1093/jn/133.9.2973S.

Hussain I, Uddin MB, Aziz MG. 2011. Optimization of antinutritional factors from germinated wheat and mung bean by response surface methodology. Int Food Res J 18: 957-963.

[Kemenkes] Pusat Data dan Informasi Kementerian Kesehatan RI. 2016. Situasi Gizi. Pusat Data dan Informasi. Kementerian Kesehatan RI, Jakarta.

Kresnowati MTAP, Turyanto L, Zaenuddin A, Trihatmoko K. 2019. Effects of microbial starter composition on nutritional contents and pasting properties of fermented cassava flour. ASEAN J Chem Eng 19: 12-24. DOI: 10.22146/ajche. 50871.

Koréissi-Dembélé $\mathrm{Y}$, Fanou-Fogny $\mathrm{N}$, Moretti $\mathrm{D}$, Schuth S, Dossa RAM, Egli I. 2013 Dephytinisation with intrinsic wheat phytase and iron fortification significantly increase iron absorption from fonio (Digitaria exilis) meals in West African Women. PLoS ONE 8: e70613. DOI: 10.1371/journal.pone.0070613.

Kumari S, Krishnan V, Jolly M, Sachdev A. 2014. In vivo bioavailability of essential minerals and phytase activity during soaking and germination in soybean (Glycine max L.). Australian J Crop Sci 8: 1168-1174.

Luo Y-W, Xie W-H, Jin X-X, Wang Q, Zai X-M. 2013. Effects of germination and cooking for enhanced in vitro iron, calcium and zinc bioaccessibility from faba bean, azuki bean and mung bean sprout. CyTA-J Food 11: 318-323. DOI: 10.1080/19476337.2012.757756.

Meitha A, Bindar Y, Kresnowati MTAP. 2016. Effects of cassava chips fermentation conditions on the produced flour properties. ASEAN J Chem Eng 16: 50-58. DOI: 10.22146/ajche.49674.

Muzquiz M, Varela A, Burbano C, Cuadrado C, Guillamón E, Pedrosa MM. 2012. Bioactive compounds in legumes: Pronutritive and antinutritive actions. Implications for nutrition and health. Phytochem Rev 11: 227-244. DOI: 10. 1007/s11101-012-9233-9.

Mohamed R, Abou-Arab EA, Gibriel AY, Rasmy $\mathrm{NMH}$, Abu-Salem FM. 2011. Effect of legume processing treatments individually or in combination on their phytic acid content. Afr J Food Sci Technol 2: 036-046.

Nakitto AM, Muyonga JH, Nakimbugwe D. 2014. Effects of combined traditional processing methods on the nutritional quality of beans. Food Sci Nutr 3: 233-241. DOI: 10.1002/fsn3. 209.

Oboh G, Elusiyan CA. 2007. Changes in the nutrient and anti-nutrient content of micro-fungi fermented cassava flour produced from low- and medium-cyanide variety of cassava tubers. Afr J Biotechnol 6: 2150-2157. DOI: 10.5897/ AJB2007.000-2336

Oghbael M, Prakash J. 2016. Effect of primary processing of cereals and legumes on its nutritional quality: A comprehensive review. Food Sci Tehnol 2: 1-14. DOI: 10.1080/23311932.2015. 1136015.

Ogodo A C, Ugbogu O C, Onyeagba R A, Okereke H C. 2018. In vitro starch and protein digestibility and proximate composition of soybean flour fermented with lactic acid bacteria (LAB) consortia. Agr Nat Res 52: 503-509. DOI: 10. 1016/j.anres.2018.10.001.

Ratnawati L, Desnilasari D, Surahman DN, Kumalasari R. 2019. Evaluation of physicochemical, functional and pasting properties of soybean, mung bean and red kidney bean flour as ingredient in biscuit. IOP Conf. Series: Earth and Environ Sci 251: 1-10. DOI: 10.1088/17551315/251/1/012026. 
Ratnawati L, Desnilasari D, Kumalasari R, Surahman DN. 2020. Characterization of modified cassava flour (mocaf)-based biscuits substituted with soybean flour at varying concentrations and particle sizes. Food Res 4: 645651. DOI: 10.26656/fr.2017.4(3).282.

Silva EO, Bracarense APFRL. 2016. Phytic acid: from antinutritional to multiple protection factor of organic systems. J Food Sci 81: R1357R1362. DOI: 10.1111/1750-3841.13320.

Schleiffer R, Galluser M, Rohr O, Raul F. 1993. Development of a technique for in situ studies of calcium absorption in the intestine of rats. Biomed Pharmacother 47: 19-23. DOI: 10.1016/ 0753-3322(93)90032-G.

Sharma S, Goyal R, Barwal S. 2013. Domestic processing effects on physicochemical, nutritional and anti-nutritional attributes in soybean (Glycine max L. Merill). Int Food Res J 20: 32033209.

Tadele Y. 2015. Important anti-nutritional substance and inherent toxicants of feeds. Food Sci Qual Management 36: 40-47.
Tajoddin MD, Shinde M, Lalitha J. 2011. In vivo reduction the phytic acid content of mung bean (Phaseolus aureus L.) cultivars during germination. American-Eurasian J Agric Environ Sci 10: 127-132.

Tanaka Y, Resurreccion AP, Juliano BO, Bechtel DB. 1978. Properties of whole and undigested fraction of protein bodies of milled rice. Agr Biol Chem Tokyo 42: 2015-2023. DOI: 10.1080/000 21369.1978.10863302.

Tsalissavrina I, Prawirohartono EP, Lestari LA. 2012. Efek F100 dan formula tepung tempe terhadap kadar serum $\mathrm{Fe}$ dan hemoglobin pada anak gizi kurang. J Gizi Klinik Indonesia 9: 2533. DOI: 10.22146/ijcn.15373.

Viswanathan K, Ho P. 2014. Fortification of white flat bread with sprouted red kidney bean (Phaseolus vulgaris). Acta Sci Pol Technol Aliment 13: 27-34. DOI: 10.17306/J.AFS.2014.1.2.

Wang X, Yang R, Jin X, Chen Z, Zhou Y, Gu Z. 2015. Effect of germination and incubation on $\mathrm{Zn}, \mathrm{Fe}$, and $\mathrm{Ca}$ bioavailability values of soybeans (Glycine max L.) and mung beans (Vigna radiata L.). Food Sci Biotechnol 24: 1829-1835 DOI: 10.1007/s10068-015-0239-0. 